\title{
O romance português contemporâneo: um espelho do mundo em transformação
}

\author{
Elisabete de Carvalho Peiruque*
}

\begin{abstract}
Resumo: A exemplo do significativo número de romances portugueses contemporâneos que revisitam o passado nacional, seja para desmistificá-lo ou remitificá-lo frente à globalização da economia e a consequente homogeneização cultural, é também expressiva a presença de uma ficção que aborda as mudanças rápidas e constantes ocorridas nas individualidades e nas relações interpessoais. É o caso dos romances em foco no presente texto, o qual analisa a importância do gênero romanesco como "espelho privilegiado do mundo" e como discurso representativo de realidades e imaginários nesse mesmo mundo em processo de transformação ininterrupta. Em Está uma noite quente de verão, de Isabel Ramos, lê-se a solidão e insatisfação das personagens, personagens essas perdidas entre o uso de drogas e do álcool e a banalização de uma sexualidade desregrada. A Flor do Sal, De Rosa Lobato de Faria sugere inquietações frente ao tabu do incesto e a necessidade de sua preservação num mundo que vem eliminando valores tidos como norteadores da vida humana.
\end{abstract}

Palavras-chave: romance contemporâneo; pós modernidade; individualidades; transformações; valores

\begin{abstract}
In line with the significant number of Portuguese contemporary novels that revisit the national past, either to demystify or to re-mystify it in relation to the globalization of economy and consequent cultural equalization, there is also an expressive presence of a fiction that approaches the rapid and constant changes which have occurred in individualities and in interpersonal relationships. That is the case with the novels being focused in this text, which analyses the importance of gender as "a privileged mirror of the world", as well as a representative narrative of realities and the imaginary in this same world which is in a constant process of transformation. In Está uma noite quente de verão of Isabel Ramos, one notices the loneliness and dissatisfaction of the characters, who are lost among the use of drugs and alcohol and a dissolute sexuality being made trivial. A Flor do Sal, of Rosa Lobato de Faria, suggests disturbing feelings towards the taboo of incest and the need of preserving it in a world that has been eliminating values which have always been considered as essential in orienting human life.
\end{abstract}

Keywords: contemporary novel; post-modernity; individualities; social transformations; values

O romance, esse Proteu que vem acompanhando esteticamente as manifestações culturais do ocidente desde o século XVIII, nos dias de hoje - e talvez mais do que nunca - dá conta do mundo e, especificamente, das muitas e rápidas transformações de nosso tempo. Como gênero recente, último a surgir no contexto cultural do ocidente, refrata, pela via

\footnotetext{
* Graduou-se em Letras pela Faculdade Porto Alegrense de Educação Ciências e Letras (1977), mestrou-se em Letras pela Universidade Federal do Rio Grande do Sul (1988) e doutorou-se em História pela Universidade Federal do Rio Grande do Sul (2003). Atualmente é professora adjunta da Universidade Federal do Rio Grande do Sul. Tem experiência na área de Letras, com ênfase em Literatura Portuguesa, atuando principalmente nos seguintes temas: Literatura Portuguesa da Idade Média, Romance Português contemporâneo (ficção e identidade nacional; ficção colonialismo e pós-colonialismo), Poesia e Conto português.
} 
estética, a multiplicidade da vida, seja ela a dos homens como coletividade, seja a do homem olhando para dentro de si, com sua solidão, conflitos e questionamentos.

A numericamente expressiva ficção portuguesa atual constitui um exemplo do que representa o romance como 'espelho privilegiado do mundo' - na feliz expressão de CalleGruber. Temas como a volta ao passado histórico e suas relações com a questão das identidades culturais nacionais frente no mundo globalizado, bem como as novas relações interpessoais transformadas estão presentes no romance português tanto no nível da representação de uma realidade irreversível como no da representação dos imaginários por ela gerados.

Os dois romances enfocados a seguir dão conta dessa última questão. A banalização do sexo, operada numa volta de cento e oitenta graus em relação ao tempo anterior e uma reflexão sobre o incesto numa época de desaparecimento de praticamente todos os valores até então tidos como verdades inquestionáveis são os temas de Está uma noite quente de verão, de Isabel Ramos, e A flor do sal, de Rosa Lobato de Faria, os dois publicados já nesse século XXI. No primeiro, lê-se uma realidade comprovada na experiência diária e, quanto ao segundo, pode-se ler uma indagação quanto ao que nos reserva este mundo novo que se desenha e redesenha à nossa frente ininterruptamente. Ambos, apesar do que os separa em termos de qualidade literária, estão interligados ao constituírem matéria para reflexão pelo fato de abordarem aspectos da vida que nos tocam profundamente e, assim, provocarem certa dose de perplexidade. Seus significados, em diferentes níveis, devem-se certamente à sua maneira de lidar de modo metafórico com a vida na sua pluralidade.

O fascínio por histórias que misturam realidade e invenção faz parte de nossa aparelhagem mental. Nosso gosto pela ficção - já presente na infância quando as histórias infantis alimentaram nossos sonhos e acalmaram nossas ansiedades - constitui o gérmen do romance e da sua receptividade, estendendo-se isso pela narrativa filmada. Gênero recente na história da literatura, o romance é considerado por Roger Caillois (1974) e Lucien Boia (1998) como documento da época de sua produção, enquanto Walter Mignolo, desmentindo a categoria unicamente representacional do romance, expressa sua crença na força do mesmo. Considera ele que o romance não deve ser lido apenas como objeto de estudo, e, sim, "como produção de conhecimento teórico; não como 'representação de algo', sociedade, idéias, mas como reflexão à sua própria moda sobre problemas de interesse humano" (2003, p. 305).

Partindo dos pressupostos teóricos acima mencionados, as reflexões que se seguem têm por objetivo examinar primeiramente o romance da escritora portuguesa Isabel Ramos, Está uma noite quente de verão, datado de 2005, como portador de uma teoria e como o 
registro muito específico de um certo tempo. A perturbação que fica no leitor, após a sua leitura, deve-se talvez ao fato de o romance - em princípio, tradução da realidade de maneira estética - dizer tão pouco, parecendo bastante colado à realidade. Isabel Ramos, num aparente 'desenredo', conta os desacertos de Mariana com a vida, numa narrativa linear, com uma voz a falar quase sempre do presente vivido a cada momento.

O mundo da personagem é o nosso mundo em processo de transformação acelerada neste tempo que se costuma chamar de pós-modernidade ou modernidade final - continuação ou oposição à modernidade (?) - e que vem sendo estudado por sociólogos como Anthony Giddens e Zygmunt Bauman. Ambos acusam como uma das suas marcas maiores a alteração das relações interpessoais. Zygmunt Bauman comenta o fato de que, apesar de mudanças terem sido sempre a tônica da vida, "nunca antes [elas] foram tantas nem tão profundas e o [seu] rápido aumento [em] quantidade e profundidade torna muito mais difícil a permanente tarefa humana da auto-orientação" (2000, p. 147 - 148). Por sua vez, Anthony Giddens afirma que:

entre todas mudanças que estão se dando no mundo, nenhuma é mais importante do que aquelas que acontecem em nossas vidas pessoais - na sexualidade, nos relacionamentos, no casamento e na família.

GIDDENS (2000, p. 61)

O panorama alterado do "mundo em descontrole" - para usar da expressão do mesmo Giddens - vai desaguar no romance, lembrando que o que está na vida vai para a arte, e de modo especial, para a narrativa ficcional - ainda que não de forma mimética.

Não chegando a convencer como obra de ficção pelas qualidades literárias, - embora levando à reflexão pelo gosto amargo que deixa sua leitura - o romance de Isabel Ramos, entretanto, apela para sensibilidades exacerbadas pelas mudanças constantes dessa modernidade tardia - porque possivelmente resultado delas -, modernidade que nos atropela com seus valores e desvalores convivendo em pé de igualdade. Huyssens (apud HARVEY, 1992, p. 45) sublinha tais sensibilidades integrantes das sociedades ocidentais como resultados de "uma notável mutação" e, dir-se-ia, inegável mutação de que o romance dá conta. Mariana vive uma relação atormentada com David e, em meio a essa confusão de sentimentos, encontros e desencontros em que se droga, bebe e fuma incessantemente, relaciona-se sem preconceitos com outros homens. O romance dá a medida de uma geração para a qual não é problema o sexo promíscuo a não ser como perigo da Aids, isto é, sem problemas morais. São suas essas palavras ao fim de mais uma aventura: "Era um final feliz para mais uma amizade colorida" (2005, p. 60). Atente-se no advérbio 'mais' como 
representação de uma idéia que veio criando corpo de modo a tornar-se a marca dos relacionamentos entre as últimas gerações.

Mariana, nem tão jovem, pois já anda perto dos quarenta anos, representa a geração que iniciou pelos finais dos anos sessenta, início dos setenta. Sua vida é o que Bauman denomina de "coleção de experiências" dessa segunda revolução sexual que temos diante dos olhos (1998, p. 184). A falta de sentido da vida, os personagens como que à deriva, a banalização do uso das drogas e do sexo que constituem a narrativa são como que um retrato das pontas do iceberg oculto que está sob nossos pés e do qual ainda não sabemos a dimensão real.

Espécie de reportagem da época em que vivemos - e por isso mesmo podendo parecer o já referido discurso por demais colado ao real -, o romance de Isabel Ramos coloca algumas perguntas nas entrelinhas. O que quererá dizer a escrita de uma vida aparentemente sem sentido? O que quererá dizer essa narrativa do sem-sentido ao lado da busca do amor, da experiência das amizades verdadeiras? Representações de um imaginário de negação dos novos comportamentos? Dentro de tal perspectiva, são significativas as opiniões de Roger Caillois e Lucien Boia sobre a narrativa de ficção. Separados por um longo período de tempo nas suas reflexões, coincidem, entretanto, em suas posições sobre o valor do romance como elemento aferidor do social. Para o primeiro, o romance deve ser estudado como um fato social, fora do âmbito das letras, não importando sua qualidade literária nesse caso $(1974, \mathrm{p}$. 161), enquanto Lucien Boia reitera tal opinião a partir de estudos mais recentes sobre o imaginário. Para esse último, "do ponto de vista da história do imaginário, a excelência literária pouco conta; ela é de modo geral menos instrutiva que a representatividade”. A partir de tal postura, ele refere a necessidade de percorrer um sem número de obras medíocres e de qualidade duvidosa para apreender "os pensamentos e sonhos de uma época" (1998, p. 44). Os dois teóricos veem os romances policiais e os folhetins, por exemplo, - e, por extensão, outras obras menores em termos de valor literário - como importantes para a decodificação de sensibilidades de um determinado tempo, lado a lado com os grandes monumentos da literatura.

A personagem Mariana é uma solitária, ainda que tenha amigos e amigas. Quer encontrar o amor que está representado - e, ao mesmo tempo, não está -, em um David que vai e volta para um convívio tumultuado, para no final cindir a vida entre o relacionamento com ele e com outro. O que fica como uma leitura possível é a dissociação entre o amor e o exercício da sexualidade sem afeto, levando a pensar os valores da juventude ou, pelo menos, da primeira onda de uma modernidade tardia esboçada nos anos setenta e agora estabelecida, 
ao que parece, para valer, com seus códigos de comportamento sendo normas para os filhos e netos dessa geração. Ainda, como saldo, fica uma reflexão sobre a banalização do que até não muito tempo era considerado como aspecto negativo das relações.

O romance em foco remete para a cultura de massa. Não se pode esquecer que essa facilita leituras com a identificação de uma sociedade que não sabe lidar com seus problemas e projeta suas expectativas de solução nos textos literários de qualidade inferior, no cinema para circuito comercial e, evidentemente, na telenovela. Dentro de tal contexto, Bauman em Amor líquido faz referência a uma série televisiva inglesa rotulando-a como repetição por falar do que é do conhecimento geral. "Reafirmações regulares e confiáveis para a pessoa insegura: sim, esta é a sua vida, e a verdade sobre a vida dos outros como você” (2004, p. 42). Está uma noite quente de verão está antes incluído na categoria de arte comercial - resultado de uma pós-modernidade - do que inserido sob o rótulo de romance pós-moderno. Narrativa linear, seguindo modelos de uma literatura tradicional, foge ao que se costuma chamar romance contemporâneo pelo alto nível de complexidade que esse carrega. Contudo, confere com a falta de profundidade das obras pós-modernas apontada por Eagleton, possível consequência talvez da tentativa da não separação entre produção erudita e produção popular. Ele vê a produção da cultura do pós-modernismo como:

[...] uma arte superficial, descentrada, infundada, auto-reflexiva, divertida, caudatária, eclética, pluralista que obscurece as fronteiras entre e a cultura 'elitista' e a cultura 'popular'.

EAGLETON (1998, p. 7)

Bauman, o sociólogo do mundo líquido, ressalta a falta de compromisso bem como a inconsistência que caracterizam as relações afetivas nos dias de hoje, fatos sobejamente retratados na vida da personagem de Isabel Ramos. E, dir-se-ia, relações superficiais, porque dão conta de um mundo dos afetos que assim o é. O romance é superficial, como sua personagem e, neste sentido, ainda um documento da subjetividade de uma época, para usar palavras de Vargas Llosa (1991, p. 19) que reiteram o pensamento de Lucien Boia.

Não sendo intenção da presente reflexão entrar especificamente nas discussões sobre o que venha a ser pós-moderno, sem que, contudo, seja possível omitir as evidentes relações, a análise centrada nas personagens indicia comportamentos típicos de nossa época. Esses estão marcados por sensibilidades para captação e para a recepção das representações do mundo líquido, no qual as experiências de hoje já saciaram os consumidores porque sua liquidez é a contínua promessa de outras e mais intensas experiências para um amanhã que vem logo após. Consomem-se relações como se consomem os objetos que a sociedade do capital produz sem cessar. Eis o que um dos companheiros de Mariana deixa explícito: "Posso te dizer que ela me 
foi muito útil, no sentido prático da questão, ou seja, através dela conheci muita gente ligada à música" (2005, p. 226). Nessa linha de pensamento, o conceito de Mireille Calle-Gruber sobre o romance como espelho privilegiado do mundo (1991, p. 12) é altamente significativo. O romance mostra o 'dentro' e o 'fora' das personagens, e é o mundo em que tudo é mercadoria que a narrativa de ficção - seja cultura de massa ou obra de valor - traz à tona.

Em nota anônima na contracapa do romance, lê-se que "esta mulher vive a vida ao seu ritmo, ciente da fragilidade e efemeridade dos sentimentos". Isso não soa como positivo, ao ser um retrato da vida que nos vai levando para onde não sabemos. Num esgotamento de emoções, o que sobrará após a corrida pelos caminhos labirínticos da busca de realizações de tais emoções distorcidas?

Mariana vive o mundo do não-pensar e do prazer avulso, - se é que pode isso pode ocorrer.

\begin{abstract}
A música era boa e estava muito alta.
Óptimo! Não teria de ouvir meus pensamentos. Era disto que eu precisava! [...] À medida que ia bebendo já no segundo copo, sentia o corpo baixar suas defesas. [...] Levantei-me, fui à casa de banho. Fantástico, este País está a evoluir: tinha um cestinho cheio de preservativos e outros mimos. On ne sait jamais, e servi-me de dois, um azul e um cor-de-rosa.
\end{abstract}

RAMOS (2005, p. 11)

A cena que aparece aos olhos do leitor configura o mundo em que a personagem vive. A voz narradora passa como evolução a comercialização do sexo e a sua inconsequiência afetiva, o que remete para a crítica irônica de Bauman a comentários 'brilhantes' de consultoras de relacionamentos em periódicos atuais de grande alcance na Inglaterra:

As promessas de compromisso, escreve Adrienne Burgess, são irrelevantes a longo prazo. O compromisso é uma consequiência aleatória de outras coisas: nosso grau de satisfação com o relacionamento [...] [e] levá-lo adiante nos causaria uma perda importante em matéria de investimentos

BAUMAN (2004, p. 28).

Bauman então observa: "Um relacionamento, como lhe dirá o especialista, é um investimento como todos os outros", e a análise do sociólogo é mordaz para explicar palavras que são espelho do mundo da mercadoria e do capital, a bem dizer, palavras do vocabulário da economia "As relações de bolso, explica Catherine Jarvie, são assim chamadas porque você guarda no bolso de modo a poder lançar mão delas quando for preciso" (2004, p. 36). Bauman conclui que a relação de bolso que a autora da expressão diz ser doce o é porque tem curta duração. "Uma relação de bolso é a encarnação da instantaneidade e da disponibilidade" (2004, p. 36). Mariana é a que está disponível para qualquer coisa que a tire da solidão cada vez maior a qual ela afoga na bebida, substituta na ausência de alguém. 
Eu vivo como quiser, à velocidade que bem me aprouver. Sou financeiramente independente, não tenho filhos, não tenho dívidas nem sócios [...] tenho meia dúzia de bons amigos, se calhar nem tanto [...] tenho 38 anos, já passei da fase de ter de provar coisas a mim própria [...] A vida é demasiado breve para isso.

RAMOS (2005, p. 15)

Na sequência dessa breve apresentação de si mesma, a personagem dá a medida de sua visão da vida em que a velocidade das transformações é claramente mencionada. É um viver, um atordoar-se na busca incessante de coisas novas nas quais as pessoas estão incluídas como objetos de troca. "Na maioria das vezes, [o sexo] é aclamado como o estágio indispensável no processo de emancipação individual" (BAUMAN, 1998, p. 184). Viver relacionamentos coloridos significa crescimento, ao que parece. Um resto da lembrança do que era a regra à moda antiga aparece na semi-censura da pergunta da amiga:

- Dormiste com ele?

- É claro que sim

- Mas... como pudeste? Conheceste-o ontem! Eu não era capaz!

- É... nesse aspecto tens razão. Demasiado fácil, não é? Mas olha, há dias em que não estamos para jogos. Apeteceu-me e aconteceu. E digo-te que foi óptimo (...).

RAMOS (2005, p. 54)

Já referido linhas atrás, é reiterado aqui o gosto amargo que fica da leitura. Por parecer um retrato fiel da realidade, sendo uma ficção que não acrescenta nada ou muito pouco e, assim, não oferece expectativas de outra coisa senão a irreversibilidade do que aí está, o romance também ratifica ao longo se sua leitura seu caráter de retrato da cultura de consumo. Bauman nos fala da verdade da arte, como ainda a concebemos, tendo por destino

opor-se à realidade e, por meio dessa oposição, compensar a vida do que lhe foi despojado pela realidade e, assim, indiretamente, tornar a realidade suportável, protegendo-a contra as consequiências de sua cegueira auto-inflingida.

BAUMAN (1998, p. 158)

Tal dimensão configura por contraponto a característica da cultura de massa que dá o 'sim' ao mundo sem questioná-lo. A narrativa da vida de Mariana constitui a aquiescência de seu tempo e que é, quer queiramos ou não, o nosso.

Representação de boa parte dos comportamentos nas sociedades urbanas no mundo atual, Está uma noite quente de verão permite inferir um modelo de vida que se vai tornando a regra por todo o lado, regra essa marcada pela ausência de estranhamentos e, portanto, constituindo a normalidade. No romance pode-se ler o desencanto, o sem-sabor de uma vida mal vivida que ilustra estudos sobre sensibilidades alteradas pelo mundo da modernidade tardia. 
- Ah, queres drogar-te?! ... - zombou o Pedro. - Olha que isso não resolve nada, muito pelo contrário. Mas está bem, apetece-te descontrair. O problema é que aqui eu não tenho nada, não há nada para ninguém. Provavelmente em casa, há por lá uma pedrinha esquecida, só procurando [...].

RAMOS (2005, p. 123)

A teoria de Mignolo, desse modo, concretiza-se quando se lê por trás de uma história até certo ponto destituída de interesse - não somente o retrato no espelho diferenciado do mundo atual (apud CALLE-GRUBER, 1989), mas uma lição que coincide com os estudos na área da sociologia. $\mathrm{O}$ romance em questão remete para o mundo em descontrole em todos os sentidos. Mariana não quer compromissos, vive cada dia em busca de não sabe o quê, porque, na verdade, nem sabe bem o que quer. A angústia que se lê - angústia de quem lê e reflete nas implicações de novos modelos de vida - não se aplaca nem mesmo na passagem final quando Mariana encontra um homem que aparentemente a satisfaz, sem, no entanto, abrir mão de David. Fica no ar a indagação sobre o que significa amar no mundo da modernidade tardia. Num tom de aparente satisfação, a personagem conclui sua trajetória e a história dela.

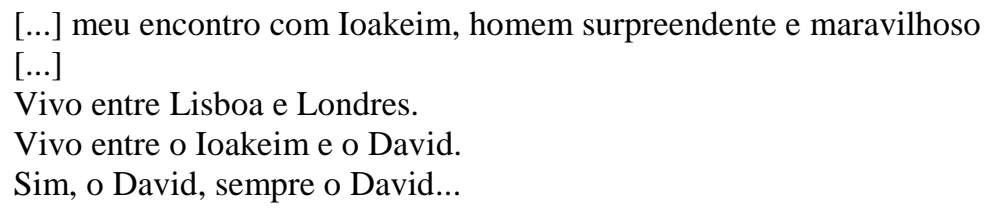

A mera observação para o que se vê à volta parece confirmar o que os estudos sociológicos mostram como marca do tempo globalizado, onde além da exportação do capital, exportam-se maneiras de ser. Raymond Williams anota "um número de importantes e contínuas reações [...] a mudanças em nossa vida social, econômica e política", ou seja, algo presente sob os nossos olhos, sejam eles críticos ou nem tanto. $\mathrm{Na}$ esteira dessa análise, afirma ele a evidente necessidade de um 'mapa' para se ler e compreender a natureza de tais transformações (apud HALL, 2003, p. 132 - 133). É, pois, possível pensar no romance de Isabel Ramos e outros que representam o mundo descontrolado como guias para sua compreensão. Está uma noite quente de verão aponta para uma realidade que vai sendo cada vez mais concebida como natural, desejável, ao mesmo tempo que os que a vivem dão mostras da insatisfação por ela causada. Neste sentido, esse romance, com seu duvidoso valor literário, torna-se um documento valioso de nossa época em que amizades coloridas pela sexualidade desregrada são a tônica e o consumo de drogas é considerado prática social natural.

Em contraposição à superficialidade da narrativa de Isabel Ramos, coincidente com a superficialidade do mundo aí representado, o romance de Rosa Lobato de Faria certamente 
tem outro status do ponto de vista literário. Lidando com a questão do incesto, pode ser lido como representação de um imaginário de inquietações quanto ao futuro da humanidade.

A leitura do romance A Flor do Sal de Rosa Lobato de Faria (2005), na sua abordagem do incesto - como tantos outros romances que tratam do tema -, suscita o questionamento de dois temas: a ambiguidade presente na essência do humano que leva ao relacionamento-tabu frequentes vezes, e, concomitantemente, a consciência de que as leis da cultura devem triunfar sobre as da natureza. Questão a ser repensada, ela extrapola o âmbito da antropologia e da psicanálise, vindo desaguar no universo da literatura, onde os sentimentos de quem escreve e os de quem lê se encontram, num misto de horror, curiosidade, compaixão. Regina Biscaro nomeia medo, angústia, atração e curiosidade - sentimentos contraditórios - em relação à experiência vivida ou conhecida (2003, p. 9).

Considerando o romance dentro do panorama da literatura portuguesa, de imediato vem à memória o grande romance de Eça de Queirós, Os Maias. O mesmo tema está presente em um romance bem mais recente, A vaga de calor, de Urbano Tavares Rodrigues. Dois exemplos apenas de relações entre irmãos, já que registros de outros tipos de relação incestuosa são encontrados aqui e ali. O conto de Joaquim Paço d'Arcos, intitulado $O$ olho de vidro, trata de um incesto cometido por pai e filha. Num primeiro momento, é possível pensar que entre irmãos poderá haver consentimento, levando-se em conta a normalmente pequena diferença de idade, sempre menor que entre pai e filha, fato esse que permite supor também uma relação de força. O referido conto de Paço d'Arcos, entretanto, desmente essa possibilidade que na vida real se sabe acontecer. E, certamente, o romance de Eça também não pode ser visto como uma relação consentida, dada a ignorância do parentesco das duas personagens do drama.

A Flor do Sal, narrativa dentro de outra narrativa ficcional - já que a personagem é uma escritora em processo de criação de um romance - conta paralelamente duas histórias que se entrelaçam. O romance que ela escreve a partir de alguma informação histórica sobre certo navegador português que teria estado na América antes de Colombo desenvolve-se lado a lado com sua história pessoal, conflitada pela relação incestuosa que mantém com o irmão gêmeo.

A frequência com que o tema aparece na literatura permite pensar no seu paralelismo com a vida. Melhor dizendo, se está na vida, termina por aparecer no romance. Para Julio Cortázar, o romance é fundamental para que o homem conheça e se conheça: "Digo então que a presença inequívoca do romance em nosso tempo se deve ao fato de ser ele o instrumento 
verbal necessário para a posse do homem como pessoa, do homem vivendo e sentindo-se viver" (1974, p. 67).

Claude Lévi-Strauss admite que não saberemos jamais como os nossos ancestrais, na organização primitiva das relações sociais, teriam chegado ao reconhecimento da dependência da ordem natural - pluralidade de famílias que reconhecem a existência de outros laços que não os da consanguinidade.

\begin{abstract}
$\mathrm{Na}$ verdade, haveria dificuldade de conceber o que poderia ser uma organização social elementar sem lhe dar por alicerce a proibição do incesto. Porque esta procede sozinha a uma reformulação das condições biológicas do acasalamento e da procriação. Ela não permite às famílias que se perpetuem senão encerradas numa rede artificial de proibições e obrigações. É apenas aí que se pode situar a passagem da natureza para a cultura, da condição animal para a condição humana e é apenas por aí que se pode compreender a sua articulação.
\end{abstract}

LÉVI-STRAUSS (1983, p. 88 - 89)

Lévi-Strauss, na sequência dessas idéias, comenta a teoria de Tylor: "O melhor, senão o único, meio para as famílias biológicas não serem empurradas para o extermínio recíproco é unirem-se entre si por laços de sangue" (p. 89). Poder-se-ia inferir daí um ato racional de interdição a partir de relações sexuais vividas - com a consequente geração de filhos e, assim, vínculos - entre pessoas de grupos diversos que terminaram por mostrar que tal situação impediria o extermínio, ou seja, foi a experiência que mostrou o caminho. De qualquer maneira, diz Héritier (1989, p. 96), Lévi-Strauss vê o tabu como "um formidável mistério".

Para Frazer, o incesto pode ter outra conotação:

Não se compreende bem porque é que um instinto humano profundamente enraizado teria necessidade de ser reforçado por uma lei. Não existem leis ordenando ao homem que coma ou que beba ou que proíbam de pôr as mãos no fogo (...) o que a própria natureza proíbe e castiga não tem necessidade de ser proibido e castigado pela lei. Por isso, em vez de deduzirmos da proibição legal do incesto que existe uma aversão natural pelo incesto, deveríamos antes concluir que há um instinto natural que leva ao incesto.

FRAZER apud HÉRITIER (1989, p. 97)

Em outros termos, dentro dessa teoria, as duas possibilidades sempre estão presentes em gérmen, ainda que a atração por consanguíneos não seja o mais comum. Não se trata de discutir aqui o mito do qual Freud fez uso, pois ali foi a ignorância do parentesco, aliada à circunstância do monstro que era o flagelo de Tebas que levou à transgressão. Entretanto, a teoria não pode ser ignorada, pois os fatos se repetem.

Ora, é tal ambiguidade, possibilidade em potencial, que está representada no romance onde um amor impossível é vivenciado entre irmãos gêmeos que se consideram uma só pessoa pois "é o meu sangue que flui no teu coração", palavras de Lourenço (2005, p. 73). Guiomar reitera essa concepção que tem de sua ligação com o irmão. "Nós dois somos [...] o 
lado feminino e o lado masculino de uma só pessoa" (p. 40), frase que é repetida pelo irmão: "Desde que te deitaram no meu berço, a nossa mãe exclamou, tenho um lindo filho dividido em dois" (p. 73). Entretanto, ele lembra-lhe que suas relações não são permitidas. "Tu não tens o sentido do pecado. Quando nascemos fui eu que arquei com o pecado original. Sou eu quem carrega a culpa" (p. 72). Ou, como Guiomar reitera mais adiante, "porque somos duas metades de um ser, tu não conheces o Mal, eu não conheço o Bem” (p. 207). Sendo gêmeos, é como se um fosse o ser humano em estado de natureza e o outro já tocado pela cultura.

A transgressão do tabu do incesto vem para a ficção sempre como ato a ser punido, sendo uma projeção do que se passa na vida real. Tanto nessa como naquela, há uma sequência que vai da transgressão à punição, passando pela culpa, pelo menos na cultura ocidental, onde a tragédia de Sófocles, retomada do mito arcaico, é uma amostra de quão de longe vem a proibição e seus correlatos. Nos romances de Eça e de Urbano Tavares Rodrigues, a punição vem pela separação e a dor que daí resulta, porque há a consciência da força do ímpeto amoroso. Octavio Paz refere-se ao amor como "esse sentimento estranho que é simultaneamente uma atração fatal e uma livre escolha" (1994, p. 95), do que o diálogo entre os dois personagens dá conta.

- Tens alguma mulher?

- És doida. Como é que eu posso? É tudo tão pequeno, tão mesquinho, tão rasteiro. Eu passo pelas mulheres mas não as quero.

RAMOS (2005, p. 72)

Lourenço foge e volta sempre porque, confessa, "és uma tentação grande demais" (p. 72).

A separação se afigura como morte e, portanto, como castigo. A morte física, real, através da autopunição, entretanto, está presente como solução fatal e final para os que têm consciência aguda de sua transgressão e de sua debilidade contra a força do amor, caso em que se inscreve A Flor do Sal e, de alguma forma, o Édipo arcaico com a morte simbólica pela cegueira auto-infligida.

O romance de Rosa Lobato de Faria trabalha com a culpa e com a autopunição. Entretanto, a culpa sentida por Lourenço não existe em Guiomar.

- Que culpa?

- Na nossa sociedade, na nossa religião...

- Não me venhas falar de religião (...)

FARIA (2005, p. 72). 
François Héritier, no seu estudo sobre o incesto, ressalta que nem sempre se olha com repulsa o ato incestuoso. Depois de assinalar o sempre citado caso dos reis egípcios, apresenta casos de interdições e regras para as relações sexuais entre parentes em grupos tribais, sejam ou não casamento, mostrando que as punições estão na ordem da sobrevivência coletiva, e sua transgressão não passa em branco. Na esteira de tais considerações, entretanto, nota Héritier, “a experiência etnológica mostra que existe universalmente, se não uma autêntica proibição do incesto, pelo menos uma tendência para regulamentar as relações sexuais entre parentes chegados" (1989, p. 96).

Dir-se-ia, contudo, que na nossa cultura, dificilmente, se encara sem um sentimento de repúdio tal situação. Talvez pelo fato de que incesto para nós significa relação entre parentes muito próximos pela consanguinidade, ao contrário da variedade de interdições que a antropologia menciona entre sociedades arcaicas, não sendo também de se esquecer a proibição de casamentos entre primos até sétimo grau no ocidente cristão medieval. Nosso repúdio, que se marca pelo horror, passa para a literatura, tanto da parte de quem escreve, como da parte do leitor. Sendo um princípio internalizado o da interdição, mesmo que jamais mencionado, ninguém o desconhece e, ao serem cruzadas as fronteiras que configurariam a ultrapassagem da natureza para a cultura, instaura-se um processo de culpa. De tal maneira o tabu está assimilado aos nossos modelos culturais que não podemos admiti-lo nem mesmo na literatura. A nossa exigência de verossimilhança na obra literária rejeitaria o romance caso ele não punisse os transgressores de alguma forma. $\mathrm{O}$ romance repete o que se passa na vida real. As relações incestuosas devem permanecer à sombra. Em A flor do sal, há a representação da consciência de transgressão, mesmo que ela não seja conhecida do grupo social.

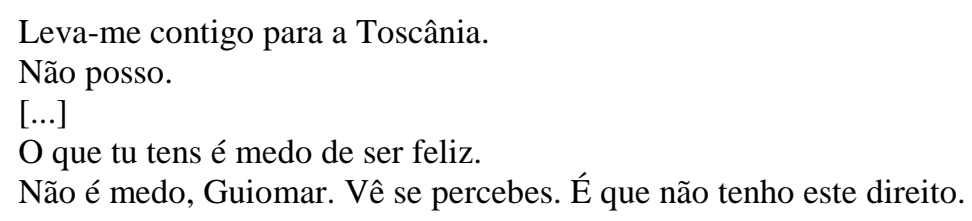

FARIA (2005, p. 90)

De certa forma, pode-se ver em Guiomar o estágio primitivo de natureza através de sua atitude quase infantil. Ou quase animal? Se esta é a marca da cultura, efetivamente ela não ascendeu a esse estágio. "Acho um crime desprezar a felicidade que nos é oferecida. Temos saúde, felicidade amor, liberdade, beleza e o mundo inteiro aqui à mão e temo-nos um ao outro. Mas para ti tudo tem que ser fatalidade" (p. 91).

Guiomar, na sua atitude de criança que não aceita proibições, observa que a vida não é uma tragédia grega, ao que o irmão responde: “a nossa é” (p. 91). 
A personagem feminina representa uma natureza indomável a qual ele tem de frear. Os dois são a representação do humano no qual ambas as potencialidades estão presentes. Poderse-ia indagar aqui como seria a inversão de papéis, isto é, Guiomar, representando a cultura e Lourenço, a natureza. Teríamos então a violência instaurada, a sexualidade agressiva, no molde dos casos em que sabe de relações incestuosas entre pai e filha, quando seguidamente a força predomina.

Considerando a absorção pelo gênero romanesco dos conflitos de que a vida é plena, pense-se nas atitudes que se tem frente ao problema real e à sua representação no discurso ficcional. Os sentimentos que vêm à tona frente a uma narrativa como A Flor do Sal são ambíguos. Se na vida real, rejeita-se absolutamente o incesto, a leitura do romance - e de qualquer outro que do mesmo tema trate - marca-se por emoções diversas, contraditórias. Com uma ficção, experimenta-se horror, mas também compaixão pelo drama vivido pelas personagens, o que leva a Aristóteles, suas definições do gênero trágico e as reações do público.

Lê-se na Poética:

Às vezes, os sentimentos de temor e pena procedem do espetáculo: às vezes também do próprio arranjo das ações, como é preferível e próprio de melhor poeta. É mister, com efeito, arranjar a fábula de maneira tal que mesmo sem assistir, quem ouvir contar as ocorrências sinta arrepios e compaixão em conseqüência dos fatos; é o que experimentaria quem ouvisse a estória de Édipo.

ARISTÓTELES (1981, p. 33)

Por sua vez, Lesky, ao comentar o problema do trágico, diz claramente que "hoje [...] nem os espectadores serão purificados das paixões cuja desmedida as personagens trágicas expiam com a própria destruição, nem se tornarão melhores ao aumentarem sua filantropia ou ao se verem livres de um excesso de emoções” (1971, p. 22). Pode-se pensar, contudo, que a literatura de ficção permite, via de regra, ver que, por trás do que há de condenável, há seres humanos com sentimentos. Identificação com a miséria humana, seria essa a questão presente na leitura do romance e, portanto, na literatura. Excluindo-se, evidentemente, casos em que a força é o motor da relação incestuosa, há que considerar como que uma armadilha da vida o fato de alguém ter desejos por outro alguém que lhe corresponde, apesar da consanguinidade. O grande romance brasileiro que é Lavoura Arcaica de Raduam Nassar sugere exatamente aquela palavra - cilada do destino? em relação ao problema vivido pela personagem.

A explicação dada pela genética não tem mais a validade que se lhe conferia no passado. Héritier assim o expressa: 
Tendo em conta que os casos de verdadeira desvantagem genética não são observáveis em larga escala, apresentam caracteres pouco especuladores e não são observáveis ou demonstráveis senão através de requintadas análises de laboratório, como poderiam os grupos primitivos alarmar-se perante perigos tão pouco manifestos a ponto de edificarem, todos, a mesma proibição com o objetivo de defender a sua sobrevivência?

HÉRITIER (1989, p. 97)

O fértil pensamento de Edgar Morin salienta a consciência que se tem hoje da interação entre a evolução biológica e o processo cultural, consciência essa dada pelo avanço científico. "De repente, afirma, desmorona-se o antigo paradigma que opunha natureza e cultura. A evolução biológica e a evolução cultural são dois aspectos, dois pólos de desenvolvimento inter-relacionados e interferentes do fenômeno total da hominização" (1973, p. 87). É o que se pode ler nos avanços e recuos de Lourenço ao longo da narrativa. Exorta a irmã a guardar o sentido das conveniências para daí a pouco se envolver amorosamente com ela (2005, p. 103). Seu discurso pode ser o da razão, da cultura, mas, logo em seguida, se deixa dominar pela força que o atrai para ela.

Da mesma forma, Guiomar representa uma natureza que não se pode dizer intocada pela cultura. Sendo aquela que nasceu sem a noção do pecado que habita a alma de Lourenço, não está completamente livre da culpa introjetada pelo complexo cultural, pois consente em morrer no pacto de morte que Lourenço arquiteta para os dois. Ela, que ama a vida e argumenta contra as proibições, termina por aceitar o suicídio porque a vida sem o amor entre os dois é insuportável, e é impossível evitar a transgressão. Ainda que entremeadas as duas facetas do ser humano, na cultura ocidental é inaceitável o relacionamento entre pessoas com uma consanguinidade tão próxima, e a morte é a confirmação da necessidade de a cultura superar os instintos da natureza, mesmo que se configure uma tragédia.

A questão levantada sobre o porquê de trazer o incesto para a literatura nos nossos dias poderia ir além do fato de o romance ser "o espelho privilegiado da vida", com a formulação de uma hipótese. Nesta nossa época de transformações aceleradas em que os costumes foram caindo um a um, como pedras de dominó, essa narrativa ficcional não poderá ser vista como representação de um imaginário de temor inconsciente pela possibilidade de uma volta ao mundo sem leis, um retorno à barbárie? Tal hipótese encontra respaldo em Elisabeth Badinter, ao analisar as transformações nas relações homem e mulher, quando afirma que o tabu do incesto perdeu "uma da justificativas mais preciosas", já que as mulheres não são mais objeto de troca. E Badinter cita Pomeroy, co-autor do célebre Relatório Kinsey, sobre o comportamento sexual dos americanos: "está na hora de reconhecer que o incesto não é necessariamente uma perversão ou uma forma de doença mental, mas que; às vezes pode ser 
benéfico" (1986, p. 153). Não sendo uma questão fechada, fica o convite à reflexão. Portanto reflitamos!

Abordar dois romances contemporâneos como registro do tempo que vivemos leva a duas afirmações bastante sugestivas. Para um historiador como Jacques Le Goff, deve-se "procurar o sentido de uma sociedade no seu sistema de representações e no lugar que tal sistema ocupa nas estruturas sociais e na realidade" (1990, p. 241), enquanto Ruskin, citado por Kenneth Clarck, (1995, p.214) afirma que as nações escrevem sua autobiografia no livro dos seus feitos, no de suas palavras e no livro da sua arte. Neste sentido, os romances de hoje - como arte da palavra - estão revelando o sentido e escrevendo a história de um mundo homogeneizado pela globalização da economia.

\section{Referências}

ARISTÓTELES, LONGINO, HORÁCIO. A poética clássica. Tradução de Jaime Bruna. São Paulo: Cultrix, Editora da Universidade de São Paulo, 1981.

BADINTER, Elisabeth. Um é o outro - Relações entre homens e mulheres. São Paulo: Círculo do Livro, 1986.

BAUMAN, Zygmunt. Amor líquido. Rio de Janeiro: Jorge Zahar Editor, 2004. . Em busca da política. Rio de Janeiro: Jorge Zahar Editor, 2000. O mal estar da pós-modernidade. Rio de Janeiro: Jorge Zahar Editor, 1998.

BISCARO, Regina. Incesto - um fenômeno arquetípico. São Paulo: Zouk, 2003.

BOIA, Lucien. Pour une histoire de l'imaginaire. Paris: Gallimard, 1998.

CAILLOIS, Roger. Approches de l’imaginaire. Paris: Gallimard, 1974.

CALLE-GRUBER, Mireille. L'Effet-Fiction - de l'illusion romanesque. Paris: A. -G. Nizet, 1989.

CALLE-GRUBER, Mireille. L'effet-fiction de l'illusion romanesque. Paris: A. -G. Nizet, 1989.

CLARCK, Kenneth. Civilização. São Paulo: Martins Fontes, 1995.

CORTÁZAR, Julio. Valise de Cronópio. São Paulo: Perspectiva, 1974. 
EAGLETON, Terry. As ilusões da pós-modernidade. Rio de Janeiro: Jorge Zahar Editor, 1998.

FARIA, Rosa Lobato de. A Flor do Sal. Porto, Portugal: Asa, 2005.

GIDDENS, Anthony. Mundo em descontrole - o que a globalização está fazendo conosco. Rio de Janeiro: Record, 2000.

HALL, Stuart. Diáspora. Belo Horizonte: Editora da UFMG, 2003.

HÉRITIER, François. Incesto. In: Enciclopédia Einaudi. Lisboa: Imprensa Nacional - Casa da Moeda, 1989.

LE GOFF, Jacques. O maravilhoso e o cotidiano no Ocidente Medieval. Lisboa: Edições 70, 1990.

LESKY, Albin. A tragédia grega. São Paulo: Perspectiva, 1971.

LÉVI-STRAUSS, Claude. O olhar distanciado. Lisboa: Edições 70, 1983.

MIGNOLO, Walter. Histórias locais / projetos globais. Belo Horizonte: Editora da UFMG, 2003.

MORIN, Edgar. O paradigma perdido. Lisboa: Publicações Europa-América, 1973.

PAZ, Octavio. A dupla chama - amor e erotismo. São Paulo: Siciliano, 1994.

QUEIRÓS, Eça de. Os Maias. Belo Horizonte: Itatiaia, 1980.

RAMOS, Isabel. Está uma noite quente de verão. Lisboa: Editorial Presença, 2005.

RODRIGUES, Urbano Tavares. A vaga de calor. Lisboa: Publicações Europa-América, 1986.

VARGAS LLOSA, Mario. La verité par le mensonge. Paris: Gallimard, 1991. 